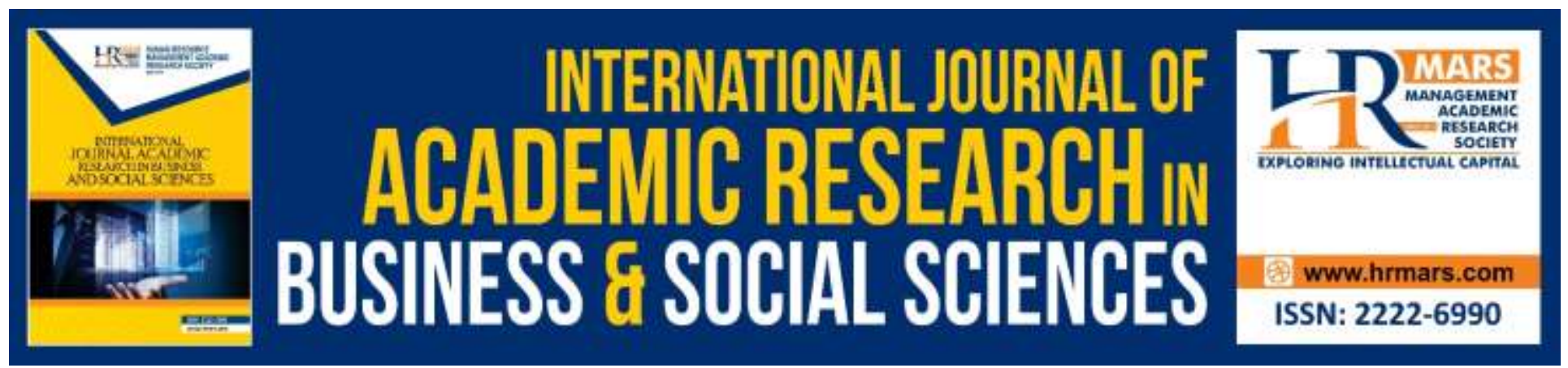

\title{
Sustainable Drug Treatment and Rehabilitation Programme in Malaysia --Empowering the Client through "555 Note Book"
}

\section{Siti Zulaikha Mustapha, Nor Hafizah Mohamed Harith \& Tuan Nooriani Tuan Ismail}

To Link this Article: http://dx.doi.org/10.6007/IJARBSS/v10-i14/7364

DOI:10.6007/IJARBSS/v10-i14/7364

Received: 24 April 2020, Revised: 29 May 2020, Accepted: 13 June 2020

Published Online: 29 June 2020

In-Text Citation: (Mustapha et al., 2020)

To Cite this Article: Mustapha, S. Z., Harith, N. H. M., \& Ismail, T. N. T. (2020). Sustainable Drug Treatment and Rehabilitation Programme in Malaysia --Empowering the Client through "555 Note Book." International Journal of Academic Research in Business and Social Sciences, 10(14), 70-81.

Copyright: (c) 2020 The Author(s)

Published by Human Resource Management Academic Research Society (www.hrmars.com)

This article is published under the Creative Commons Attribution (CC BY 4.0) license. Anyone may reproduce, distribute, translate and create derivative works of this article (for both commercial and non-commercial purposes), subject to full attribution to the original publication and authors. The full terms of this license may be seen at: $\underline{\text { http://creativecommons.org/licences/by/4.0/legalcode }}$

Special Issue: WSTI2018 - Issues and Trends on Education, Science and Technology, 2020, Pg. 70 - 81

Full Terms \& Conditions of access and use can be found at http://hrmars.com/index.php/pages/detail/publication-ethics 


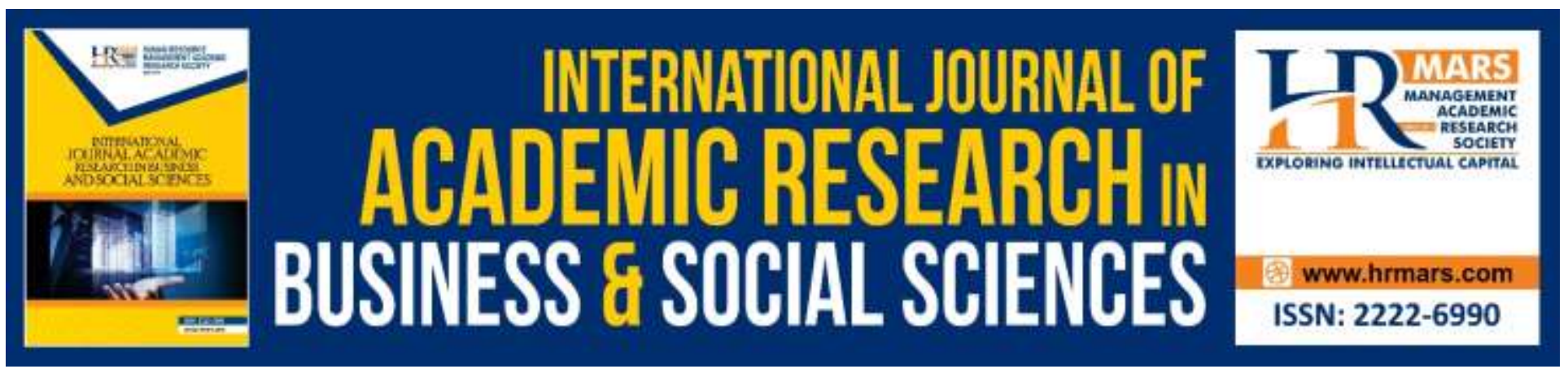

\title{
Sustainable Drug Treatment and Rehabilitation Programme in Malaysia --Empowering the Client through "555 Note Book"
}

\section{Siti Zulaikha Mustapha, Nor Hafizah Mohamed Harith \& Tuan Nooriani Tuan Ismail}

Faculty Administrative Science \& Policy Studies, University Teknologi MARA (UiTM) Selangor Malaysia

Email: sitizulaikhabtmustapha@gmail.com,norha561@uitm.edu.my, tnsya800@salam.uitm.edu.my

\begin{abstract}
Malaysia began to highlight Sustainable Development Goals (SDGs) in 2015. One of the targets is to strengthen the prevention and treatment of drug abuse. The recovery process among drug abuser always threatened with relapse issues. 555 Note Book is one of the initiatives proposed to empower them to sustain their recovery. Two strategies are highlighted by inculcating trust and building selfconfident. This initiative is equipped with user friendly characteristics, ease of use and a Malaysian way to portray trust. Therefore, this initiative could be one of the approaches to reduce relapse and sustain the drug treatment programme in Malaysia.
\end{abstract}

Keywords: Empowering Client, Sustainable Drug Treatment and Rehabilitation, 555 Note Book, Relapse.

\section{Introduction}

Millennium Development Goals and Sustainable Development Goals (SDG's) are among the crucial blueprints to guide the developed and developing country in dealing with economy, social and environment issues (Economic Planning Unit, 2017). The commitment to achieve the sustainable development goals has lead to improvement, changes and transformation in development and policy, in every country (Biron, 2015). This paper focuses on ensuring the sustainable development of drug treatment and rehabilitation programme in reference to Malaysia context. The journey of treating and rehabilitating the drug addicts or any individual who involved with drug issues remain as the responsibility of many parties such as the government, private sectors, Non-Governmental Organizations, society, family and the individuals themselves. Despite of this, the demand and supply of drug in the world including Malaysia keep increasing and there is no end to this problem. World society acknowledged the danger of drug especially in terms of social and health issues. The commitment and focus to achieve SDGs has been put in place and resulted to significance progress particularly in the aspects of drug treatment and rehabilitation. Nevertheless, in achieving the goals, 
human capital plays the most important role. To strengthen the treatment and prevention of drug addiction, the drugs addict or client is the main focus. Therefore, through social innovation, the initiative of 555 Note Book has been developed to assist and empower individuals who involved with drug addiction to enhance their recovery from relapse.

\section{Mapping the Implementation of Drug Treatment and Rehabilitation with SDG's}

The journey of sustainable development in Malaysia is actually not a new approach. It has been known since 1970 - 60 years ago the country has known sustainable development. Nevertheless, at that time, little efforts were undertaken to fulfil the aims of implementing sustainable development. After 30 years, in year of 2000, United Nations has highlighted the significance of sustainable development by introducing Millennium Development Goals (MDGs). Only 8 goals were highlighted, mainly on the extreme issues such as poverty, hunger, inequality of gender, combating diseases, health issues and environment as well as development. The blueprint of MDGs is agreed by all countries and world leading development institutions such as World Health Organization (WHO), World Bank, UNICEF (UN Children's Fund), International Labour Organization (ILO) and more. The goals proposed are ambitious but feasible due to the elements of MDG. According to Ban Ki-moon, United Nations Secretary General (2002) in his speech, it has been mentioned that MDG has strong elements comprised of time bound target, promoting crucial aspect namely; gender, health, education that can be measured and embodied basic human right in each goals. Therefore, the world including Malaysia has undertaken their role in upholding the sustainability in the development of the country.

Nevertheless, after 15 years of the implementation of MDG in Malaysia, it has contributed to the achievement of few targets such as the increase of women participation and reducing poverty as all states only have less than 1 percent poverty rate except for Sabah and Regional of Labuan (Economic Planning Unit, 2017). However, not all the targets were achieved as the country have not achieve the target of halting the incidence of tuberculosis by 2015 (Economic Planning Unit, 2017) and to free Malaysia from the drug addiction threat by 2015 (National Anti-Drugs Agency, 2015). However, the failure or ineffectiveness in achieving the MDGs target is not the main issue to be argued here as the process of curbing drug issues is very complex and required continuous efforts. Therefore, the introduction of SDGs by United Nations in 2015 is to be continued for the next 15 years and once again, Malaysia has supported the agenda. Thus, from 2015 until 2030, another 17 sustainable development goals has been introduced with more comprehensive targets and indicators. This paper highlighted the goal number 3 of SDGs that is to ensure healthy lives and promote well-being for all at all ages. The focus is more on the target of 3.5 (to strengthen the drug prevention and treatment).

Figure 1.0 presents the map of the implementation of drug treatment and rehabilitation with SDGs in Malaysia. The mapping consists of 3 important parts; (1) Journey of Sustainable Development, (2) Drug Policy in Malaysia and (3) Drug Treatment and Rehabilitation Programme. The detailed explanations are as follows: 
INTERNATIONAL JOURNAL OF ACADEMIC RESEARCH IN BUSINESS AND SOCIAL SCIENCES

Vol. 10, No. 14, Special Issue: WSTI2018 - Issues and Trends on Education, Science and Technology, 2020, E-ISSN: 2222 -6990 @ 2020 HRMARS

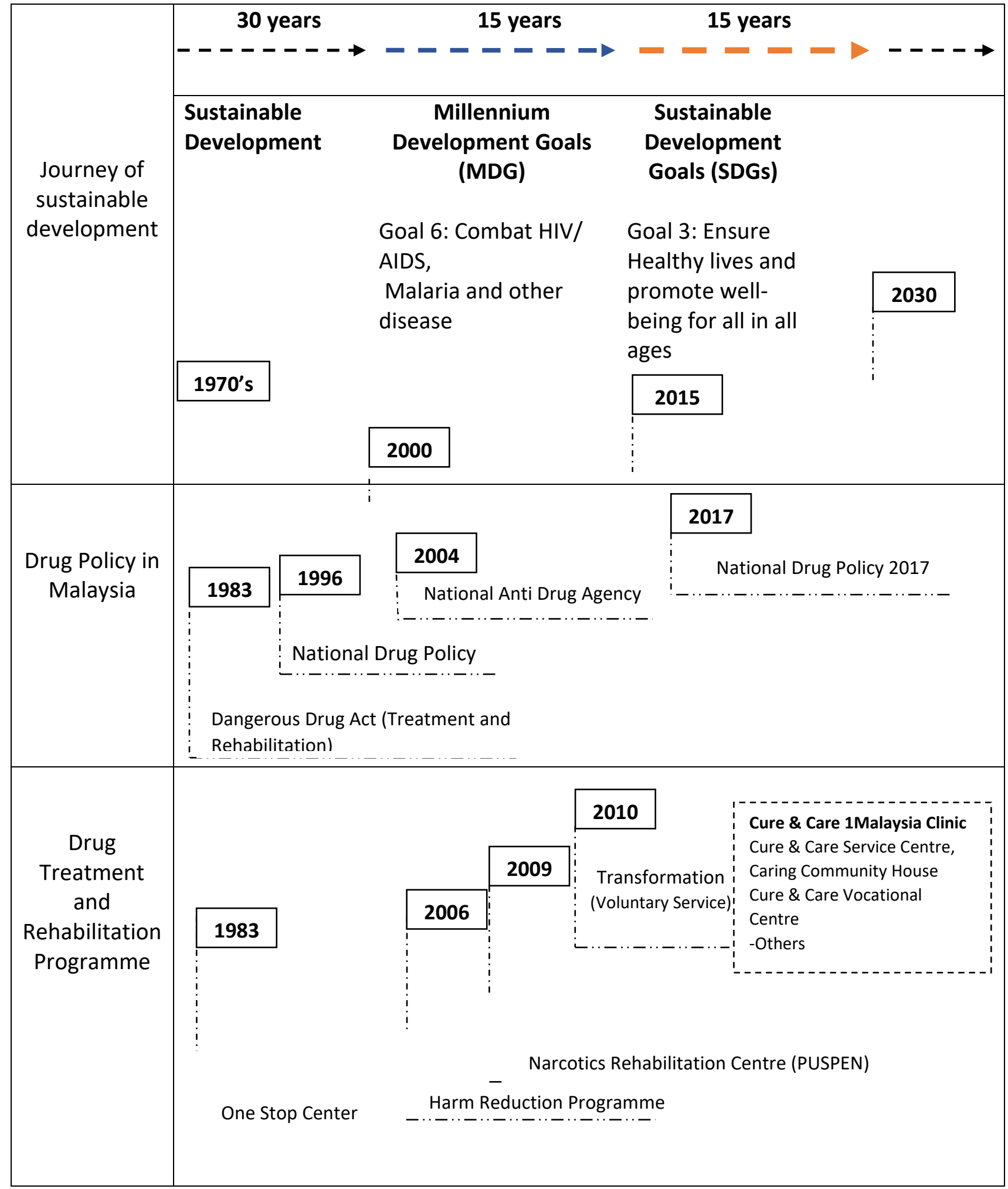

Figure 1.0: Mapping the Implementation of Drug Treatment and Rehabilitation with SDG

In reference to Figure 1.0, in Malaysia, drug issue is the only issue until in the early of 1970's, whereby the pattern of drug addiction has changed from few traditional types of drug (cannabis) to 
modern drugs (heroin, morphine) and the addiction involving youth from all races (Malay, Chinese, India) instead of older person (Kamarudin, 2007). This is the impact of free mobilization of people to the country, end of cold war, low awareness on the danger of drug and changes of social trend. For instance, in 1970's, youth had moved from rural to urban areas due to industrial revolution. The gap of 13 years between the outbreaks of drug issues in 1970's to 1983 cost the country to have drug addicts with HIV-positive due to the injecting drug use. The multiplying effects of injecting drug use have lead to the epidemic of HIV-positive among the female i.e. wife and their children. The transmission of HIV and AIDS has caused the death of people. According to United Nations Office on Drug and Crime (2015), among the total population of the world, there are 13 million people who injected drug and they are believed to be HIV-positive. Thus, this trend is similar to other countries such as India, Indonesia, China, Vietnam, Myanmar, Thailand, United States and more (UNAIDS, 2017).

Hence, under the legislation of Dangerous Drug Act (Treatment and rehabilitation) 1983, the government has provided the facilities besides financing the efforts to control the spread of drug addiction. One stop centre is the first drug treatment and rehabilitation programme which provided the treatment and rehabilitation programme but the drug addict was forced under legal proceeding. The implementation of one stop centre has been criticized as due to the 70 to 90 percent of the drug addict relapse, little medical care and the drug addicts were treated like criminals (Tanguay, 2011). The drug treatment programme was designed to be in military style and harsh due to the adoption of punitive approach. After 23 years of the implementation of one stop centre, only then, harm reduction programmes such as Methadone Maintenance Treatment (MMT) and Needle and Syringe Exchange Programme (NSPs) were introduced. The aims are to curb drug addiction and halt the spread of HIV/AIDS in Malaysia. The treatment and rehabilitation approach has slowly move towards health approach as the harm reduction programme focused more on health issues than punishment to the drug addicts. By referring to Figure 1.0, starting the year of 2000, the government has embedded the MDGs in dealing with drug addiction in Malaysia. This effort has been strengthen with the establishment of National Anti-Drugs Agency in 2004, to cater the drug issues in Malaysia. Harm reduction programme has shown the positive changes in the landscape of drug addiction by enhancing the compliance of drug addicts to treatment, change the addictive behaviour and stop taking the drug (heroin) (Jeganathan Premila et al., 2012; Kamarulzaman, 2009; Mukherjee et al., 2016) .

Consequently, in 2009, following the impact of harm reduction programme, former Prime Minister Dato' Sri Mohd Najib Abdul Razak has announced the new name of one stop centre to Narcotics Drug Treatment or PUSPEN. The new branding of the drug treatment centre shows that the government is aware of the bad perceptions of the society regarding drug addicts. As at this time, the government has stated to view drug addiction as a health issue instead of security or crime issue. However, in terms of treatment and rehabilitation programme, the concept is still similar with one stop centre. The influence of sustainable development goal has embraced in the evolution and transformation of drug policy and drug treatment and rehabilitation programme in this country. In facing the new era of administration, in 2010, the government has undergone transformation era whereby the government has executed voluntary services and transformed the branding and services of drug treatment and rehabilitation centre. As one of the Government Transformation Programme (GTP), the new image of drug treatment centre has been classified into few divisions which known as 
Cure \& Care project, the programme which promoting human right, health issues and development of government services (Mohamed \& Marican, 2014; National Anti-Drugs Agency, 2012).

The drug treatment and rehabilitation programme is provided based on evidence, systematic and it is sustainable in treating the drug addiction issues. The coverage of the centre is also wider and it covers all the hot spot of drug addiction both in rural and urban community. The outcomes of the transformational program has reduced street crimes to 16.9 percent from the original KPI to reduce crime, (PEMANDU, 2015) and the statistic of drug addiction and relapse has been reduced for 3 years (2010, 2011,2012) with a total of 22 percent of reduction. Nevertheless, the performance of the transformations of drug treatment and rehabilitation programme continued to show the increase of the number of drug addict and relapse each year. This ponders the questions is why this situation happened? Are there dilemmas to achieve this target? This also indicates that drug addiction is a very complex issue and the goals of sustainable development should be improved from time to time.

\section{Achieving Sustainable Drug Treatment and Rehabilitation: Issues and dilemmas}

Drug is the number one enemy is the campaign promoting the resentment and creating awareness on the dangerous against drug. This campaign started in 1983 to show the seriousness of the government in dealing with drug problems. Furthermore, this campaign was also implemented in America since 1971, whereby drug abuse is regarded as number 1 public enemy (Barber, 2016). It is difficult to measure the effectiveness and the success of the initiatives and efforts regarding this matter. On behalf of policy planning as presented in Figure 1.0, the strategies looks perfect and this is also similar with other country too, such as United States, Thailand, Indonesia and more. This matter required in-depth understanding from the bottoms of the problems. Therefore, this paper has addressed the dilemma in achieving the sustainable drug treatment and rehabilitation as follows:

\section{Health Concern Policy versus Economic Purpose}

This section particularly discussed on the dilemma of the implementation of World Health Organization Framework Convention on Tobacco Control (FCTC) in all countries. This is the first legal instrument which promotes the multi cooperation and national action to combat the tobacco epidemic in the world (Roemer, Taylor, \& Lariviere, 2005). The important of the implementation of FCTC is the efforts to curb the actual root of drug addiction. The habit of tobacco smoking is closely related with alcohol and drug use (Roemer et al., 2005). The authors argued that; there are similar factors that influence the addiction of cigarettes smoking, alcohol and drug such as peers influence and dependency. Besides, tobacco industry promote product (cigarette, e-cigarette) that is proven to be addictive and can cause disease and death. Thus, it is highlighted in SDGs through target 3.a strengthen the implementation of FCTC to uphold the public health concern more than economic purpose. Yet, on behalf of tobacco industry, the introduction of new tobacco products in the country has caused dilemma to the implementation of the public policy. The government has to implement price policy by increasing the taxes to the industry and price of cigarette to reduce the consumption of this harmful product. The price policy on tobacco control benefited more to the society as it is the win-win efforts as the government can save lives and gain the revenue from the industry taxes (Framework Cnvention Alliance, 2015). 


\section{Effectiveness of Drug Treatment versus Increment of the Statistics of Drug Problems}

As stated in the previous section, the country has undergone many phases of drug treatment and rehabilitation efforts from punitive approach to health approach and evidence based. The questions of the effectiveness of the implementation of the programme always become the main concern of the country. Transformation era in 2010 has provided the positive impact to the effectiveness of the programme and the reduction of the number of statistic of new drug addicts and relapse cases. However, after almost 10 years of the implementation of transformation programme particularly Cure \& Care project, the effectiveness of the programme has declined. The statistic shows that 52.4 percent increment of the cases was recorded from $2012(15,101)$ to $2016(31,764)$ (National Anti-Drugs Agency, 2017). Do this statistic is enough to claim that the effectiveness of the drug treatment and rehabilitation programme has become ineffective? On the other hand, the statistic can also portray that the Cure \& Care project has been successful in providing their services as more drug addicts can access the services. Another argument is the growing number of the world population particularly in Malaysia has contributed to the higher number of drug addiction statistic. The justification and arguments on this matter has become the dilemmas in achieving the sustainable drug treatment and rehabilitation in Malaysia.

\section{Planning Versus Implementation of Drug Treatment and Rehabilitation Program}

The fast and growing number of drug abuse trends such as emergence of new types of drug abuse, and multi-drug addicts, various range of addicts (children, youth, adult) have required the planning of the new policy, approaches and programme to be implemented. For instance, among the programme available for drug treatment and rehabilitation are therapeutic community, psychosocial, harm reduction programme as well as evidence based programme, required a comprehensive planning. However, the capabilities of the human resources who act as counsellor, clinical and administrative staff challenged the implementation of drug treatment and rehabilitation programme (Chie et al., 2016; Vicknasingam \& Mazlan, 2008). Based on National Anti-Drugs Agency, (2016) the issues of lack of number of expertise in handling the programme has been acknowledged.

In addition to this, the planning of the new approaches in drug treatment and rehabilitation requires new module and new knowledge as well as new skills to be provided to the human resource. The negative impact of social media is also proven to be one of the latest challenges in drug treatment and rehabilitation. The study of Bollinger et al. (2010) indicates that; the pictures of peers having good times due to alcohol and drug abuse has attracted teens to involve with those addiction. The gaps in terms of the usage of technology and media social have also influenced the effectiveness of the drug treatment and rehabilitation programme. This is also one of the relapse trigger which will affect the recovery of the individual who involved with drug addiction. Thus, without the flexibility and creativity in the implementation of the programme by the staff or counsellors, the process of recovery among the client will always become challenging.

\section{Empowering Client with Education and Support through the Idea of 555 Note Book}

"Education is the most powerful weapon to change the world" (Mandela, 2003), likewise in dealing with the issues of drug treatment and rehabilitation and other social issues such as poverty, homelessness, crime, and etc. Hence, to embrace the sustainability development in the implementation drug treatment and rehabilitation, education would empower the drug addicts to deal with their addiction and drug dependency. Most of the effort regarding education are usually 
being emphasized on prevention strategies, for instances, National Anti-Drugs Agency has implemented the prevention programme to educate the youth before involving with drug problems. On the other hand, the education and support from the drug treatment and rehabilitation institutions are crucial. A study conducted by Dhand, (2006) proves that; the act of educating and training the drug addicts to deal with their addiction struggle has empowered them to have more effective recovery towards not only themselves but also to other drug addict peers. Therefore, 555 Note book is one of the initiative developed by the researcher to empower the clients in dealing with their addiction and enhance the recovery. Further discussions on this innovation are as presented below.

\begin{tabular}{|c|c|c|c|c|c|}
\hline \multicolumn{6}{|c|}{ Empowering the Client through the Idea of 555 Note Book } \\
\hline \multicolumn{3}{|c|}{ Focus of 555 Note Books } & \multirow{3}{*}{$=$} & Strategies & Outcome (short \\
\hline $\begin{array}{c}\text { Provide } \\
\text { additional } \\
\text { support }\end{array}$ & \multirow[t]{2}{*}{+} & $\begin{array}{l}\text { Educate the } \\
\text { clients about } \\
\text { channeling } \\
\text { relapse trigger } \\
\text { into motivational } \\
\text { approach }\end{array}$ & & \multirow[t]{2}{*}{$\begin{array}{l}\text { Inculcate Trust, } \\
\text { Build Confidence \& } \\
\text { motivation to not } \\
\text { relapse }\end{array}$} & $\begin{array}{l}\text { 1. Reduce } \\
\text { relapse } \\
2 . \text { Enhance } \\
\text { recovery } \\
3 . \\
\text { Independence }\end{array}$ \\
\hline $\begin{array}{l}\text { 1. Words of } \\
\text { the day } \\
\text { 2. Life lines } \\
\text { 3. Survival } \\
\text { skills }\end{array}$ & & $\begin{array}{l}\text { 1. Strategies to } \\
\text { change } \\
\text { 2. Know the } \\
\text { strengths and } \\
\text { weaknesses } \\
\text { 3. Mix \& match } \\
\text { strengths and } \\
\text { weaknesses }\end{array}$ & & & $\begin{array}{l}\text { a. Strengthen } \\
\text { the } \\
\text { effectiveness of } \\
\text { Drug treatment } \\
\text { and } \\
\text { rehabilitation } \\
\text { b. Sustain the } \\
\text { SDGs targets } \\
\text { and indicators } \\
\text { c. Reduce drug } \\
\text { addiction } \\
\text { problems } \\
\text { among } \\
\text { Malaysians }\end{array}$ \\
\hline
\end{tabular}

Figure 2.0: Descriptions of 555 Note Book's Idea and the Empowerment of Client

The original idea of 555 Note Book was proposed as one of the initiatives to enhance drug recovery among the client in Cure \& Care 1Malaysia clinics. Drug relapse triggers such as peer, environment, family, society are the main challenges for them. However, drug relapse poses a main challenge to curb drug addiction. Hence, in this initiative, three strategies has been highlighted which are, to inculcate trust and build confidence and motivation to not relapse among the client. 
The first part of the initiative involving the focus to empower the client such as provide additional support and educate the clients about channeling relapse triggered into motivational approach -in terms of support, words of the day (believe and trust yourself), survival skills (respect yourself and others) and life lines (counselor number). While in terms of additional education -there are three elements that are involved such as strategies to change (contact your positive peers), know the weakness and strengths (dreams, negative peers) and mix \& match strengths and weaknesses (change the job, make yourself busy).

In promoting the empowerment of the clients to avoid relapse, this 555 Note Book acts as an informal self- motivation tool. The uniqueness of the initiative is in terms of user friendly characteristics such as small, slim and handy and able to provide convenience feeling to the user. Moreover, only basic skills are needed to utilize this initiative such as reading and writing. The content also comprised of simple language and instruction and only crucial information and knowledge to educate the client was stated. This is in line with the traditional usage of 555 note book whereby its functions are to write down and remind the client on important matters. This initiative also portrays the Malaysian way to inculcate trust and when 555 Note Book is mentioned, everybody has recognized and accepted its functions and characteristics. 555 Note Book is a popular small book used to keep records and information. It is believed that through this initiative, the clients have the guidance and self- motivate tools to assist them after finishing the treatment and rehabilitation programme in any centre.

Hence, the outcome of this initiative such as it can reduce relapse, enhances their recovery and they appeared being independent to assist themselves to prevent from relapse. Meanwhile, there are many other initiatives such as job placement and community services. However, this initiative could be the most appropriate for the client to empower themselves to end the history of drug addiction and starts new life. Consequently, this will strengthen the effectiveness of drug treatment and rehabilitation programme, sustain the SDGs' target and indicators and reduce drug addiction problems among Malaysian. This 555 Note Book has been awarded with Gold Medal in International, Invention, Innovation \& Technology Design Competition (ITEC) 2018 on 27th February 2018 at Universiti Teknologi MARA (UiTM) Rembau, Negeri Sembilan.

\section{Recommendations and Conclusions}

Two recommendations are suggested to strengthen the drug treatment and rehabilitation programme in Malaysia. First, to achieve the sustainable development goals, more support on research and development should be carried out. Although, internationally the universal guidance from WHO, UN, UNODC and more are crucial. However, it is more effective and comprehensive if the approach is localised and executed based on local need and suitability. The effort to empower the society and curb the issues of drug addiction and relapse cases is different geographically, socially and even demographically. Research and development will promote quality products and services through innovations, inventions and publications to deal with drug addiction problems. For instance, 555 Note Book is one of the outcomes of research and development, which will benefit the clients and individuals who involved with drug addiction problems.

The second recommendation is to increase health financing and the recruitment, development, training and retention of health workforce. According to Figure 1.0, the process of planning the sustainable guideline and policy continue to meet the requirement and demand from international body. Yet, the most crucial part is that; the government should prepare the human 
capital to be at par with the planning. The economic challenge and social problems evolution demand the capable and enough experts, specialists and staff to implement and deliver the new idea or module in drug treatment and rehabilitation programme. Therefore, the effectiveness of the programme implemented will have long-term effectiveness and the clients or targeted group will receive a quality service and treatment. Hence, the clients are able to grab the skills, knowledge and free themselves from drug addiction. Finally, the sustainable development goals will be achieved and it will free the world and the society from drug abuse, addiction and dependency.

Sustainable development goals (SDGs)' agenda aims to make a world a better place to live in for the future generation. While drug addiction problems are complex issues which are interconnected with many aspects such as social, economic and politics, the combination of the current efforts in drug policy and drug treatment and rehabilitation will enhance the effectiveness of its implementation. Through the mandate, many improvements, transformations and developments have been embraced by Malaysia to curb the issues. However, there are always dilemmas and challenges which become the barrier in the success of all the agenda prepared. Regarding this matter, the effort should not only cater from up to bottom which focuses on the planning of the policy and guidelines, yet the real problems which is individuals or client should be focused on. The government has provided the evidence based programme and spend many resources (monetary and nonmonetary). Therefore, it is the time to empower the client or individuals who involved with drug addiction to be independent and self-motivate themselves. The process of recovery should be transferred to the clients or individuals, instead of depending on the service or treatment from the providers (National Anti-Drugs Agency, Cure \& Care centre and etc.).

\section{Acknowledgement}

This paper was produced based on innovation initiative and part of doctoral research. Specials thanks to Graduate Researchers in Print (GRiP) family, especially to GRiP fasilitator, Associate Professor Dr Yarina Ahmad, GRiP members, Siti Nur Fathanah Abd Hamid, Nur Amalina Azizi, Aslinda Ramely, Mohammad Nasirudin Aziz, Arifha Mohamed and other members. Thank you for all your constructive comments and guidance in completing this article.

\section{References}

Ban, Ki-moon. (2002). United Nations Millennium Campaign. Speech presented at United Nations Millennium Campaign. Retrieved April 14, 2018, from http://www.un.org/millenniumgoals/bkgd.shtml

Barber, C. (2016). Public enemy number one: a pragmatic approach to America's drug problem. Retrieved April 15, 2018, from https://www.nixonfoundation.org/2016/06/26404/

Biron, C. L. (2015). How will the SDGs impact on developed countries? Retrieved April 16, 2018, from http://citiscope.org/habitatlll/news/2015/05/how-will-sdgs-impact-developedcountries

Bollinger, L. C., Burns, U. M., Chenault, K. I., Dolan, P. R., Foster, W. H., \& Ph, D. (2010). National Survey of American Attitudes on Substance Abuse XV: Teens and Parents. Substance Abuse, (August).

Chie, Q. T., Tam, C. L., Bonn, G., Dang, H. M., \& Khairuddin, R. (2016). Substance abuse, relapse, and treatment program evaluation in Malaysia: Perspective of rehab patients and staffusing the 
INTERNATIONAL JOURNAL OF ACADEMIC RESEARCH IN BUSINESS AND SOCIAL SCIENCES

Vol. 10, No. 14, Special Issue: WSTI2018 - Issues and Trends on Education, Science and Technology, 2020, E-ISSN: 2222-6990 @ 2020 HRMARS

mixed method approach. Frontiers in Psychiatry, 7(MAY).

http://doi.org/10.3389/fpsyt.2016.00090

Dhand, A. (2006). The roles performed by peer educators during outreach among heroin addicts in India: Ethnographic insights. Social Science and Medicine, 63(10), 2674-2685.

http://doi.org/10.1016/j.socscimed.2006.06.026

Economic Planning Unit. (2017). Voluntary National Review Report 2017. Putrajaya.

Framework Convention Alliance. (2015). How to take "FCTC Implementation" from the Sustainable Development Goals (SDGs) and translate it into action in-country. Geneva 3, Switzerland.

Premila, J. D., Ab Rahman, A., Mohd, W. Z., Noor, M. A., \& Abdullah, N. H. (2012). The effectiveness of methadone maintenance therapy among opiate-dependants registered with hospital raja perempuan zainab II Kota Bharu, Kelantan. Malaysian Journal of Medical Sciences, 19(4), 1823.

Kamarudin, A. R. (2007). The misuse of drugs in Malaysia: Past and present. Journal Antidadah Malaysia, 1(2), 1-24. http://doi.org/10.2307/3820309

Kamarulzaman, A. (2009). Impact of HIV prevention programs on drug users in Malaysia. JAIDS Journal of Acquired Immune Deficiency Syndromes, 52, S17-S19.

http://doi.org/10.1097/QAI.0b013e3181bbc9af\r00126334-200911011-00006 [pii]

Mandela, N. (2003). Lighting your way to a better future. Johannesburg, South Africa: Nelson Mandela Foundation. Retrieved from http://db.nelsonmandela.org/speeches/pub_view.asp?pg=item\&ItemID=NMS909

Mohamed, M. N., \& Marican, S. (2014). Positive outcomes of Cure and Care Community Centres ( CCSC ): a community based treatment programme in Malaysia. International Journal of Prevention and Treatment of Substance Use Disorders, 1(2), 71-83. http://doi.org/http://dx.doi.org/10.4038/ijptsud.v1i2.7700

Mukherjee, T. I., Wickersham, J. A., Desai, M. M., Pillai, V., Kamarulzaman, A., \& Altice, F. L. (2016). Factors associated with interest in receiving prison-based methadone maintenance therapy in Malaysia. Drug and Alcohol Dependence, 164, 120-127. http://doi.org/10.1016/j.drugalcdep.2016.04.037

National Anti-Drugs Agency. (2012). Agensi Anti Dadah Kebangsaan Addiction Management Best Practice. Selangor. Retrieved from wecareweserve.org/wpcontent/themes/aadkmicrosite_purple/download/02_Model_C\&C_in_Malaysia_Eng.pdf

National Anti-Drugs Agency. (2015). Dasar Dadah Negara, (1), 3-5. Retrieved from http://www.adk.gov.my/html/pdf/Buletin/dasardadahnegara.pdf

National Anti-Drugs Agency. (2016). Pelan strategik 2015-2020 Agensi Antidadah Kebangsaan. Agensi Antidadah Kebangsaan Kementerian Dalam Negeri. Kajang, Selangor. Retrieved from http://www.adk.gov.my/web/guest/buku-pelan-strategik

National Anti-Drugs Agency. (2017). Maklumat dadah 2016. Kajang, Selangor.

Pemandu. (2015). National Transformation Program: Annual Report 2015. PEMANDU. Putrajaya.

Roemer, R., Taylor, A., \& Lariviere, J. (2005). Origins of the WHO framework convention on tobacco control. American Journal of Public Health, 95(6), 936-938. http://doi.org/10.2105/AJPH.2003.025908

Tanguay, P. (2011). Policy responses to drug issues in Malaysia. London. Retrieved from http://ssrn.com/abstract=1908799 
UNAIDS. (2017). Ending Aids Progress Towards the 90-90-90 Targets. Global Aids Update. Geneva 7, Switzerland. Retrieved from

http://www.unaids.org/sites/default/files/media_asset/Global_AIDS_update_2017_en.pdf United Nations Office on Drugs and Crime. (2015). World drug report 2015. New York.

Vicknasingam, B., \& Mazlan, M. (2008). Malaysian drug treatment policy: An evolution from total abstinence to harm reduction. Jurnal Antidadah Malaysia, 3 \& 4, 107-122. Retrieved from http://www.adk.gov.my/html/pdf/jurnal/2008/5.pdf 